\title{
Social assistance and dignity: South African women's experiences of the child support grant
}

\author{
Gemma Wright ${ }^{1} \odot$, David Neves ${ }^{2}$, \\ Phakama Ntshongwana ${ }^{3} \&$ Michael Noble $^{4}$
}

\begin{abstract}
Many women interact with the South African social security system in relation to the Child Support Grant (CSG), which is social assistance payable for children living with low-income caregivers. This paper explores women's accounts of how the CSG serves to protect and respect dignity, a foundational value in the South African Constitution. Drawing from focus groups and in-depth interviews with female CSG recipients of working age, it is argued that whilst the experience of using the CSG does protect dignity in certain important respects, other aspects including the application process, the small amount of the grant and negative discourses associated with the status of being a CSG recipient were experienced by many as erosive of dignity.
\end{abstract}

Keywords: South Africa; social assistance; dignity

\section{Introduction}

This paper presents an analysis of South African women's accounts of their experiences of the Child Support Grant (CSG) in terms of how it intersects with their sense of dignity. The CSG is a form of social assistance which is payable in South Africa for eligible children with low-income caregivers (RSA, 2004; Lund, 2008), more than $98 \%$ of whom are female (Fultz \& Francis, 2013). Importantly, however, there is no social assistance for the caregivers of the children themselves, unless they are either disabled and eligible for the Disability Grant, or aged 60 or over and eligible for the Old Age Grant.

Although the CSG is aimed at contributing to the needs of the child and not the caregiver, CSG receipt is intrinsically intertwined with women's experiences of social security, in their role as a 'conduit of policy' (Molyneux, 2007:37). Goldblatt depicts this role as follows:

Women mediate social assistance and deliver it on behalf of the state. They claim it, collect it and are then expected to turn it into food, shelter, clothing,

\footnotetext{
${ }^{1}$ Senior Research Fellow, Oxford Institute of Social Policy, University of Oxford, UK (at time of writing); Professor Extraordinarius, Archie Mafeje Research Institute, University of South Africa, Pretoria, South Africa; and Research Director, Southern African Social Policy Research Institute, PO Box 23069, Claremont, Cape Town 7735, South Africa. Corresponding author. gemma. wright@ saspri.org

${ }^{2}$ Senior Researcher, Institute for Poverty, Land and Agrarian Studies, University of the Western Cape, Robert Sobukwe Road, Bellville 7535, South Africa.

${ }^{3}$ Director, Missionvale Campus, Nelson Mandela Metropolitan University, PO Box 77000, Port Elizabeth 6031, South Africa.

${ }^{4}$ Emeritus Professor of Social Policy, Oxford Institute of Social Policy, University of Oxford, Oxford, UK; Visiting Professor, Rhodes University, Grahamstown, South Africa; Honorary Fellow, Human Sciences Research Council, Pretoria, South Africa; and Executive Director, Southern African Social Policy Research Institute, PO Box 23069, Claremont, Cape Town, 7735 South Africa.
} 
education, health and other aspects of a child's maintenance through their own labours. [...] Unemployed, impoverished women (and some girls) are expected, without any means to feed themselves (or meet any of their other needs), to provide child care services for the society, in exchange for nothing. (Goldblatt, 2005:242)

There has been extensive research on the impact of the CSG, which is currently paid at the rate of R310 per child per month (approximately US\$295). As well as helping to reduce income poverty - albeit to a lesser extent than the grants for adults, which are paid at a much higher rate (Hall \& Wright, 2010) - the CSG has been shown to have a number of positive impacts on children. For example, the CSG has a small but positive impact on child school enrolment (Budlender \& Woolard, 2006) and is associated with reduced levels of stunting (Agüero et al., 2006) and of child hunger (e.g. Williams, 2007). Early CSG receipt improves cognitive development and reduces the likelihood of child illness and of risky adolescent behaviour (DSD et al., 2012; Cluver et al., 2013) and the grant has been hailed as 'one of Government's most successful social policy tools for combating child poverty' (UNICEF, 2014:18). ${ }^{6}$

Less research has been undertaken to explore the impact of the CSG on the adults who receive the grant on behalf of beneficiary children. Eyal and Woolard (2011) have identified an association between CSG receipt and the likelihood of the caregiver being in the labour force. Patel et al. (2012) found that the CSG enhances women's power and control in household decision-making over finances, whilst Hochfeld \& Plagerson (2011) interviewed eight women from the same study and cautioned that while the CSG helps to reduce the stigma of poverty, the negative discourses around CSG receipt are experienced as stigmatising and such attitudes are sometimes applied towards other CSG recipients.

However, this paper has a different focus: that of women's accounts of their experiences of the CSG in terms of how it intersects with their dignity. As such, the analysis is underpinned by discourses on human rights - of which social security and dignity are examples (UN, 1948:Articles 1 and 22) - and on social security as a manifestation of the social rights of citizenship (e.g. Marshall \& Bottomore, 1992; Esping-Andersen, 1989; Dean, 2007). It has been widely acknowledged that extreme poverty is a violation of dignity (e.g. UN, 1993). As a form of social security provision, it is therefore possible to hypothesise that the CSG would - by helping to reduce poverty - serve to protect and respect dignity. In this paper we explore the extent to which this is supported by evidence.

The analysis presented in this paper is predicated on the understanding that, as well as being a foundational value within the South African Constitution (RSA, 1996; Chaskalson, 2000) that connotes 'innate, priceless and indefeasible human worth' (Ackermann, 2000:541), dignity can also be considered as a psycho-social phenomenon which may be eroded or undermined (e.g. Budowski, 2005). Consequently, one of the overarching objectives of the broader study from which this paper draws was to explore the synergies and tensions between 'dignity as principle' (as seen in the Constitution and jurisprudence literature; e.g. RSA, 1996; Ackermann, 2000; Chaskalson, 2000; Liebenberg, 2005) and the relatively underexplored lived

\footnotetext{
${ }^{5}$ Exchange rate on 11 July 2014.

${ }^{6}$ For a more comprehensive review, see Martin (2014).
} 
experience of 'dignity in practice'. Many attempts to explore the latter have occurred in the health arena (e.g. Chochinov et al., 2002; Haddock, 1996). In particular, a study by Khatib \& Armenian (2010) identified four dimensions of dignity - worthiness, selfrespect, self-esteem and autonomy - and as will become evident these resonated well with the arising findings.

The following section briefly summarises the methodological approach adopted. This is followed by three sections on women's experiences of the CSG as either 'respecting and protecting' their dignity or eroding their dignity: the CSG application process, the CSG as a source of income, and the status of being a CSG recipient within the wider community. The final section concludes with policy recommendations for ways in which the CSG could be modified and implemented in a manner that is more closely tied to the constitutional commitment to respect and protect people's dignity.

\section{Methods}

Thirty focus groups and 16 in-depth interviews were undertaken in the Eastern Cape and Western Cape in South Africa with low-income women between November 2011 and June 2012. Just fewer than 200 women took part in the focus groups, most of whom were 'single, never been married' (81\%). The respondents lived with an average of 1.8 children. Their home languages were isiXhosa (84\%), Afrikaans (10\%) and English $(6 \%)$, which are three of the 11 official languages in South Africa. Most of the participants were unemployed $(86 \%)$, with the remainder mainly being in parttime employment and only four women being full-time employed. The women were recruited from paypoints ${ }^{7}$ for the CSG; 13 of the focus groups were in rural former homeland areas, five in rural townships, and 12 in peri-urban townships. The focus groups were undertaken in the first language of the women.

At the start of each focus group, participants were read the section of the South African Constitution which states that 'Everyone has inherent dignity and the right to have their dignity respected and protected' (RSA, 1996:Ch2 s10). The versions in isiXhosa and Afrikaans were taken directly from the official translations of the Constitution, which respectively translate dignity as isidima and menswaardigheid. As such, the clause from the Constitution was intentionally used to catalyse a discussion about what dignity means for the participants in the contexts of their own lives. This elicited a rich set of accounts of 'dignity in practice', with participants identifying easily with the concept of dignity. Importantly, participants' accounts of 'dignity in practice' resonated strongly with Khatib and Armenian's four dimensions of dignity, and included being valued, respected, able to fulfil important roles in life, and able to provide for oneself and others. Whilst being intrinsically linked to participants' selfidentities, dignity was also portrayed as a relational value which is violable (Wright et al., 2014). The second half of the focus group schedule - the main findings of which are presented in this paper - explored with participants how the experience of applying for, receiving and using the CSG intersects with their sense of dignity.

Sixteen informants were sampled for in-depth interviews from the focus group participants, in a diverse selection of urban and rural sites, in order to elucidate key dynamics underlying CSG recipients' experiences of dignity. The female informants were interviewed in their first language, typically in their homes, and with the aid of a

\footnotetext{
${ }^{7}$ Locations where grants are paid out by independent contractors on behalf of the government.
} 
semi-structured interview schedule that broadly followed a three-part structure. The first part elicited basic information about the research participant's household, social networks, labour and life history. In contrast with the explicit foregrounding of dignity in the focus group interviews, the objective of the in-depth interviews was to obtain an expansive sense of the participant's livelihood activities and understand the place of the CSG in these. The second set of questions focused on experiences of grant receipt, including asking the research participant to narrate specific accounts of grant collection and use. The third and final sequence of questions built on the rapport of the interview and elicited insights on wider community perceptions of grant receipt, grant recipients and the specific interviewee.

In the in-depth interviews the research sought to allow the discursive space for the concept of dignity to be defined inductively, and did not impose it a priori. In this way, the in-depth interviews were a useful adjunct to the extensive focus group interviews.

\section{Dignity and applying for the Child Support Grant}

People wishing to apply for the CSG are required to go to their nearest South African Social Security Agency (SASSA) office, where the application form is completed in the presence of an official (SASSA, 2013a:5). The qualifying requirements include that the primary caregiver must be a South African citizen, permanent resident or refugee; the applicant must be the primary caregiver of the child/children concerned; the child/children must be under 18; the income of the applicant (and spouse if they have one) must fall below the means test threshold; ${ }^{8}$ and the child aged between seven and 18 years must attend school $^{9}$ (2013:4). Although it used to be necessary for the applicant to have a South African ID book and birth certificate for the child, this is no longer a requirement because, in principle, alternative forms of identification can be provided (2013:4).

SASSA has made great strides in promoting access to and take-up of the CSG. ${ }^{10}$ However, in 26 of the 30 focus groups, participants raised issues about ways in which the application process impacted negatively on their dignity. A number of studies have highlighted problematic features of the application process (e.g. Budlender et al., 2005; Goldblatt et al., 2006; DSD et al., 2012; SASSA \& UNICEF, 2013). The findings presented here are specifically oriented towards ways in which the issues intersect with women's sense of dignity and so complement earlier studies.

Three main issues with the application process which impacted on dignity were raised by women in the focus groups. ${ }^{11}$ Although a small number of women stated that they had no difficulties with the application process, these were outweighed by negative accounts, in both urban and rural areas. Women reported being made to feel unworthy by being required to queue for very lengthy periods, having to negotiate burdensome and unclear qualifying criteria, and being treated disrespectfully by government officials.

\footnotetext{
${ }^{8}$ In 2012 the means-test was R33 600 per year for a single caregiver and R67 200 per year if the caregiver had a spouse.

${ }^{9}$ Introduced in January 2010 (RSA, 2009).

${ }^{10}$ See Delany et al. (2008) and SASSA \& UNICEF (2013).

${ }^{11}$ The date of CSG application was not captured for each participant and so it is acknowledged that the timing of the applications will span several years.
} 
Queuing repeatedly or for very lengthy periods was experienced as being erosive of dignity because it implies that the women's time is not important and that they are unworthy of speedier service. For example:

I had to queue, a number of times, from five in the morning, applying for the CSG. [...]At 4pm, the SASSA staff just gathered their stuff, took their bags and left. Without explaining or saying anything to us, they simply left when they were meant to. Dignity? Where? Where is it? (Masiphumelele) ${ }^{12}$

Mention was made of arriving at the SASSA offices well before they opened sometimes on the evening beforehand, or before dawn on the relevant day - so as to ensure that their application would be processed that day. In at least five of the urban focus groups, women further mentioned that by queuing in the dark in order to be near the front of the queue, they were having to risk their personal safety. As a woman from Khayelitsha elaborated:

Criminals, rapists are everywhere at that time. They know exactly where to stand to find a vulnerable woman. (Khayelitsha)

A large number of women also raised the issue of the lack of clarity about the qualifying criteria for the grant and the great lengths to which they have to go to provide the necessary documentation. Participants reported that they felt they did not possess sufficiently clear information prior to going to the SASSA office to make the application. This meant that, after what was often a long wait in a queue, people were often turned away and told to return with additional information, sometimes on multiple occasions, making the application process much more costly in terms of time, travel and other transaction costs. The point was repeatedly made that this was detrimental to the applicants' sense of dignity. For example:

You are sent from pillar to post, all the while you are starving, hunger written all over your face, where's the dignity in that? (Khayelitsha)

In addition, many women made the point that the application process was detrimental to their sense of dignity because they were not treated with respect by officials. In some cases, SASSA officials behaved as though the grant payments came from their own pockets. For example:

It takes away our dignity, people from SASSA, they don't respect us. Even if people from SASSA were here, I would tell them the same. They do not know how to talk to people as human beings. They treat us like we're begging for that money, like it's theirs. (Khayelitsha)

Such behaviour serves as an example of social security not being regarded as a constitutional right by the SASSA staff in terms of how they interact with the applicants, but rather was implicitly cast in the register of patronage or personal beneficence. A number of women made the point that they felt unable to defend themselves by challenging the behaviour of the people administering their applications because this might prejudice their application, and gave accounts of having to be overly deferential to people who did not treat them with respect. An important general feature of perceived lack of respect was the absence of consideration for the women's circumstances. Examples given included lack of consideration for the fact that they had had to queue early and for long hours, were tired and hungry:

\footnotetext{
${ }^{12}$ Focus group place names shown in parentheses.
} 
We come here because of the pain of hunger at home, not because we want to. We are desperate. Why then is there no compassion as SASSA? Why do they treat us any which way they want? (Mbekweni)

As well as making general points about being treated without respect, a large number of women gave accounts of receiving pejorative comments in relation to their caregiver, parental or marital status. In spite of research that dismisses a link between the introduction of the CSG and teenage fertility rates (Makiwane et al., 2006), there is an ongoing and tenacious discourse within communities and the media that reinforces the notion of the CSG providing a perverse incentive for reproductive decision-making, fostering rumours that women become pregnant in order to receive the CSG as an income stream (Goldblatt, 2005). Numerous such accounts were given, for example: being asked how they can have so many children without a husband (Butterworth); being asked why they are always being abandoned by the fathers of their children (Nyanga); telling a woman that the child's father should be taking care of the child (Langa); telling a woman that she is too young to have a child (Xesi, Butterworth); and accusing them of becoming pregnant in order to receive the grant (Khayelitsha, Langa, Nyanga). ${ }^{13}$ For example:

They swear at us, the government officials, they say we have children to get the grant. We sit there until we get it, we have no choice. (Nyanga)

Following successful application, monthly collection of the CSG is accomplished in a number of ways: it is physically collected from paypoints, can be paid into a bank account, or can be obtained through an electronic SASSA payment card which can be used at participating stores. Far fewer issues were raised by the focus group participants - positive or negative - about the intersection between their sense of dignity and the process of regularly collecting the CSG than about the application process. However, some focus group participants raised issues about queues (Mitchells Plain, Lavender Hill, Xesi), fights in queues (Dimbaza, Khayelitsha) and officials speaking brusquely or pejoratively (Thafalofefe, Khayelitsha). Perhaps because of the regularity of the payment process - a monthly activity rather than a once-off process for the application - there was more mention of the issue of public scrutiny. For example (see also Section 5):

A person stands in the queue and people walk past you and then they say aloud you are standing in the queue for Allpay [the organisation paying out the grant] and all that stuff saying we don't deserve it. (Lavender Hill)

\section{Dignity and the Child Support Grant as a source of income}

The CSG is a type of income maintenance and as such by definition helps to alleviate poverty as well as having other positive outcomes (see for example Neves et al., 2009; Du Toit \& Neves, 2009b; Patel et al., 2012). However, receipt of the grant was not experienced by women as wholly protective of dignity, and dignity-eroding aspects of the grant were also reported. In this section we present findings relating to how the CSG as a source of income intersects with women's sense of dignity, focusing mainly on usage of the grant. There were no notable differences between the responses in urban and rural areas.

\footnotetext{
${ }^{13}$ This issue was also identified in a study by Goldblatt (2005).
} 
In response to the enquiry concerning how the CSG was actually used, a prominent theme in informants' accounts was the manner in which the grant served to strengthen and underwrite their dignity. Most tangibly, grant receipt served to elevate consumption and ameliorate poverty, allowing recipients to discharge their childcare responsibilities, act in ways congruent with the maternal role and, finally, exercise individual agency.

The CSG allows recipients to meet some of their children's basic needs, and thereby ameliorate some of the extreme consequences of poverty. Informants readily described grant income being directed to the major categories of food, clothing and schoolingrelated expenses more generally (crèche fees, school lunches, school transport). Grant receipt was also experienced as positive in relation to dignity in slightly less direct ways, by strengthening practices of inter-dependency and mutuality between recipients and others in their kin and social networks. These practices of social reciprocity are often key to the lives of impoverished South Africans (Du Toit \& Neves, 2009a).

It was regularly stated by participants that the CSG is a vital source of income and as such does help protect their dignity. For example:

The CSG helps protect my dignity because without it I would have nothing, at all. (Butterworth)

Within the focus groups, the main reason given by the focus group participants as to why their dignity should be protected and respected was because of their caregiver role. The inability to fulfil this role, for example being unable to provide for their children, was expressed as very damaging to their sense of dignity. When asked about how receipt of the CSG intersects with their sense of dignity, some women made the point that the CSG helps them in terms of their ability to provide for their children. For example:

The CSG helps protect my dignity. It helps my child a lot even though I'm not working. When he's with other children he has some of the things that they have because of the grant. (Centani)

However, most comments (still in response to the question about how receipt of the CSG intersects with people's sense of dignity) turned quickly to the question of adequacy of the CSG, and in particular its inadequacy for meeting the costs of raising children. The point was repeatedly made that whilst the CSG helps, it is not enough, although it is 'better than nothing' (Masiphumelele). For example, in Qumrha a group of women spoke of how the CSG only enables them to feed their children well for part of each month, and how they have to borrow from loan sharks for the second half of the month. Some women went so far as to say that the CSG does not protect their sense of dignity at all, as the amount of the grant is so small compared with what they need. For example:

The grant is so little, it doesn't help protect my dignity at all. (Butterworth)

What I'm saying is that the CSG does not protect my dignity, at all, it's not enough to do that for me or my children. (Langa)

In some of the focus groups, dissatisfaction and anger were expressed towards government about the level at which it is set, the small payment increases that are made each year for the CSG (Khayelitsha, Dimbaza) and, in one case, of being instructed by a social worker to save from the CSG for the child's future (Qumrha). 
Others spoke of how the small size of the grant suggested to them that the government was concerned about neither their dignity nor their social rights as citizens. For example:

When you sit down and consider dignity and social grants - well, the money is too little to, it does not meet the needs of our children. It's like government is looking down on our sense of dignity as poor people. It's our government, we voted them into power. We suffered under the apartheid government, now we continue to suffer because government is not looking after us as citizens well. That's all I want to say. (Nyanga)

\section{Dignity and the status of being a Child Support Grant recipient in the wider community}

In what way does the status of being labelled as a CSG recipient impact on dignity, in terms of how recipients interact with other members of their communities? Several women, particularly in urban areas, made the point that their status as a CSG recipient erodes their dignity as they become the object of people's prejudices and judgements within their communities. These attitudes are fuelled by the prominence of the dependency culture discourse in popular consciousness, the media and even some parts of the state (Surender et al., 2010; Hochfeld \& Plagerson, 2011) and again by unsubstantiated concerns that women are becoming pregnant in order to receive the CSG (Makiwane et al., 2006). For example, one woman describes how she has to contend with these comments:

It lowers your dignity. Even if you're pregnant and you get in a taxi, people pass comments that we get pregnant in order to get the grant. You end up arguing with them that the R250 is not enough even for the child. Please stop saying people fall pregnant for the grant. Even at home they say that. (Nyanga)

A second woman observes that whilst the CSG helps to protect her dignity because it enables her to help her children, her dignity is also affected negatively by the CSG because her employed peers look down on her for receiving the grant:

I'm just going to speak as I see it or according to my experience because you said there is no wrong answer. I think it's crucial for people's dignity to be protected, especially women, young and old. For example, the fathers of our children don't support them, that's an indignity. The CSG can both protect and erode your dignity. It helps with the children on the one hand, but there's [...] people my age with jobs that do not need the CSG, they tend to undermine one, you know, look down on us. That affects my dignity, negatively. (Nyanga)

In fact, far from increasing their standing within the community, a number of women described the CSG as being used by people to verbally diminish their dignity. For example:

Even though the grant is intended for good, people use it, verbally, to erode our dignity. (Butterworth)

We need this grant but it comes at a very high cost, it costs us our dignity at the end of the day. (Masiphumelele) 
Thus, whilst use of the CSG can serve to protect dignity by helping caregivers to provide for their children, it can simultaneously be experienced as detrimental to dignity.

\section{Discussion}

The findings from the study raised contradictory points. On the one hand, women spoke of how the CSG helps ostensibly to protect and bolster their dignity. In particular, as a vital income stream it enables them to provide better for their children and therefore fulfil their role as caregiver, which has a direct bearing on their maternal identity and sense of dignity.

On the other hand, the point was repeatedly made that the CSG application process was detrimental to women's sense of dignity; and the CSG payment is so small a sum that it does little, if anything, to protect their sense of dignity. Not only is the CSG seen as insufficient to provide for their children's (and their own) material needs, but for some the small amount signified that the state has little consideration for their dignity, in terms of their worthiness for support. Furthermore, recipients of the grant additionally have to contend with dignity-eroding dynamics within their communities in relation to their status as CSG recipients. Far from providing them with greater autonomy, for some the CSG was paradoxically emblematic of their lack of autonomy and their inability to obtain paid work.

Based on the empirical material, the application process for the CSG was described as particularly adverse in terms of its impact on recipients' dignity. The issues raised most frequently were those of lengthy queuing, burdensome and unclear qualifying criteria, disrespectful officials, and receiving pejorative comments about their caregiver, parental or marital status. Although the process of collecting the CSG on a monthly basis raised fewer issues, it will be important to monitor the impact of the new payment card in this regard in future studies.

These dynamics have a number of implications. First, the dignity-eroding opprobrium, disapproval or stigma from others associated with being a CSG recipient can be somewhat independent of the ways in which the CSG is used in practice. This accounts for the diverse and even contradictory ways in which recipients experience and report CSG receipt as, for instance, protective of dignity in some respects but erosive in others. Second, dignity-impairing dynamics may occur simultaneously with potentially dignity-protecting CSG use, which appeared to be an experience of several of the in-depth interview informants. Third, for some recipients these parallel dynamics may counterbalance each other, or one might predominate over another.

The analysis presented suggests that there are a number of ways in which the design and implementation of the CSG could be improved to reduce or eliminate the dignity-eroding aspects that have been identified by women who claim the CSG on behalf of the child. In doing so, this would ensure that social security provision was more closely aligned to the constitutional commitment to respect and protect dignity, and that social security design was more consistent with the constitutional recognition of social security as a social right of citizenship.

The study has identified aspects of the CSG design and implementation that - based on the accounts of some of the claimants - could be categorised as significant shortcomings. Far from being experienced as 'transformative', for some women certain aspects of their experience of the CSG were described as erosive of their dignity, arguably an antithesis 
of the transformative project (Devereux \& Sabates-Wheeler, 2004; Devereux \& McGregor, 2014). Similarly, although the grant's design may have been fuelled by principles of social justice, by de-racialising the former State Maintenance Grant, this came at the high cost of removing the caregiver component of the former grant (Lund, 2008). As a result of this policy choice and ongoing challenges of implementation, certain aspects of the experience of the CSG in practice provide us with clear examples of how unpaid care work by (mainly) women is profoundly undervalued (Goldblatt, 2005; Chopra et al., 2013), and structurally reinforces injustice (Hickey, 2014).

\subsection{Encourage public discussion about the adequacy of the CSG}

There is a growing call for a public debate on the adequacy of the CSG (e.g. Delany et al., 2008; DSD, 2008; Zembe, 2013; Martin, 2014). The CSG's adequacy affects not only the child directly but, as seen here, the dignity of the caregiver is compromised if unable to meet the needs of the child. A recent study has revealed widespread support for raising the CSG, with $71 \%$ of respondents in a nationally representative survey agreeing that the amount of CSG should be raised - a little (31\%) or a lot (40\%) - even if this meant higher taxes (Noble et al., 2008:13).

\subsection{Communicate grant eligibility criteria more clearly to potential CSG applicants}

The White Paper on Transforming Public Service Delivery, referred to as the Batho Pele ${ }^{14}$ White Paper, highlighted how 'lack of information and complex regulations are also barriers to good service' (RSA, 1997:14). It would seem that there is still a need for ongoing efforts to raise awareness about not only the eligibility criteria but also the supporting documentation required for CSG application. The point has been well made by others about the detrimental impact - to achieving receipt of the CSG - of the burdensome application process (e.g. Goldblatt, 2005; Goldblatt et al., 2006; Delany et al., 2008; DSD et al., 2011, 2012; SASSA \& UNICEF, 2013; Zembe, 2013; Martin, 2014). In addition to impeding take-up, burdensome application processes represent an externalising of administrative cost onto applicants, and are experienced as detrimental to applicants' dignity because they imply that the applicant's time, opportunity and transaction costs are unimportant.

\subsection{Retain a focus on training officials in people-centred service delivery}

There is a stated commitment within the government to treat people with respect. For example: 'Public servants are expected to treat all citizens with courtesy, respect and dignity' (RSA, 1997:5). More recently the Department of Social Development has produced a Customer Service Charter (DSD, 2013), which amongst other things states that people have the right to be treated with dignity in adequate conditions, and to expect friendly and helpful service from respectful, responsible and competent officials.

In spite of this, accounts of poor treatment of applicants by officials suggests that further in-work training and management is urgently needed on conduct (see also Goldblatt et al., 2006; Martin, 2014) as well as on the principle of social security as a social

\footnotetext{
${ }^{14}$ Batho Pele means 'People first' (see final section 6).
} 
right of citizenship. Such training would need to acknowledge and address the broader social discourses that fuel the pejorative treatment of recipients within some communities and may well influence the behaviour of local officials towards applicants.

\subsection{Remedy the systemic issues that make grant application and receipt onerous and undignified}

The research suggested both systemic and personal-related factors are at play in making the grant application process (and to a lesser extent the collection process) onerous and dignity-eroding. In common with other studies, the issue of queuing was raised as being problematic (Budlender et al., 2005; Goldblatt et al., 2006; SASSA \& UNICEF, 2013). The recurrent nature of the problem and its negative impact on dignity, as depicted by the participants in this study, suggests keen attention to queues and queuing is still warranted.

\subsection{Universalise the CSG}

More substantively, many of the issues explored here - especially those relating to dignity-eroding aspects of applying for the CSG and being a CSG recipient - could be remedied by universalising the CSG, which is already under consideration within the Department of Social Development (DSD, 2008). Universalisation of the CSG by removing the means test would reduce the number of hurdles in the application process (particularly the considerable burden of providing evidence of no income) and would be an investment in child development (e.g. Goldblatt et al., 2006; Delany et al., 2008; OECD, 2011; Martin, 2014). In the context of this study it is additionally attractive because it would remove at a stroke any association with the caregiver's income or employment status. In so doing, the CSG would cease to be emblematic of the caregiver's poverty status or lack of paid work, but instead would only reflect the fact of there being a child in the family. Given the high eligibility rate for the CSG, universalisation would be a marginal extra cost and could, if so desired, be taxed back from high-income caregivers.

Although in the context of high levels of poverty the CSG would inevitably continue to be a resource that is competed for within poverty-stricken households and families, the removal of the means test would reduce the scope for the CSG to be instrumentally harnessed by communities to reduce the dignity of recipients by making them the object of pejorative comments.

\subsection{Extend social security provision}

More broadly, although the CSG is of vital importance for children and their families, it cannot be expected that child poverty could ever be eliminated if the needs of the wider family in which they live are not taken into account.

In parallel with measures to increase labour market opportunities accompanied by affordable and high-quality childcare, social security provision should be extended to include low-income adults of working age (see for example DSD, 2008; Whitworth \& Noble, 2008). There is a constitutional commitment to achieve the progressive realisation of access to social security including social assistance for people and their dependants who are unable to support themselves (RSA, 1996:Ch2 s27), and this would also be in line with commitments across the Southern African Development 
Community (SADC, 2003, 2007). Not only would this reduce overall levels of poverty and therefore serve to help to protect people's dignity - but it would also eliminate the moral hazard of caregivers having to use the CSG for their own needs, or the indignity of dependence on others, in the absence of any social security for their own material needs.

\section{Acknowledgements}

The authors would like to thank all of the research participants for their time and contributions to the study from which this article was drawn. The study was undertaken as a collaboration between the University of Oxford, the University of the Western Cape and the Human Sciences Research Council.

\section{Disclosure statement}

No potential conflict of interest was reported by the authors.

\section{Funding}

The study was supported by the UK Department for International Development and the Economic and Social Research Council [ESRC ES/I033130/1].

\section{ORCID}

Gemma Wright (D) http://orcid.org/0000-0001-5377-5705

\section{References}

Ackermann, L, 2000. Equality and the South African constitution: The role of dignity. Heidelberg Journal of International Law 60, 537-56.

Agüero, JM, Carter, MR \& Woolard, I, 2006. The impact of unconditional cash transfers on nutrition: The South African child support grant. SALDRU Working Paper Number 06/08. SALDRU, University of Cape Town, Cape Town. Accessed 4 August 2014.

Budlender, D \& Woolard, I, 2006. The impact of the South African child support and old age grants on children's schooling and work. International Labour Office, Geneva. http://www.ilo.org/ ipec/Informationresources/WCMS_IPEC_PUB_4464/lang-en/index.htm Accessed 4 August 2014.

Budlender, D, Rosa, S \& Hall, K, 2005. At all costs? Applying the means test for the child support grant. Children's Institute \& Centre for Actuarial Research, University of Cape Town, Cape Town. http://www.ci.org.za/depts/ci/pubs/pdf/poverty/resrep/AtAllCosts.pdf Accessed 4 August 2014.

Budowski, M, 2005. Dignity and daily practice: The case of lone mothers in Costa Rica. Lit Verlag, Munster.

Chaskalson, A, 2000. Human dignity as a foundational value of our constitutional order. South African Journal of Human Rights, 16, 193-205.

Chochinov, HM, Hack, T, McClement, S, Kristjanson, L \& Harlos, M, 2002. Dignity in the terminally ill: A developing empirical model. Social Science and Medicine 54, 433-43.

Chopra, D, Wanjiku, KA \& Iyer, P, 2013. A feminist political economy analysis of public policies related to care: A thematic review. IDS Evidence Report No. 9. Institute of Development Studies, Brighton.

Cluver, L, Boyes, M, Orkin, M, Pantelic, M, Molwena, T \& Sherr, L, 2013. Child-focused state cash transfers and adolescent risks HIV-infectionin South Africa: A prospective-scorematched case-control study. The Lancet Global Health 1, e362-70. 
Dean, H, 2007. Social policy and human rights: Re-thinking the engagement. Social Policy \& Society 7(1), 1-12.

Delany, A, Ismail, Z, Graham, L \& Ramkissoon, Y, 2008. Review of the child support grant: Uses, implementation and obstacles. UNICEF South Africa, Pretoria. http://www.unicef.org/ southafrica/resources_8165.html Accessed 4 August 2014.

Devereux, S \& McGregor, JA, 2014. Transforming social protection: Human wellbeing and social justice. European Journal of Development Research 26, 296-310.

Devereux, S \& Sabates-Wheeler, R, 2004. Transformative social protection. IDS Working Paper 232. Institute of Development Studies, Brighton.

DSD (Department of Social Development), 2008. Strategic considerations for a comprehensive system of social security: Discussion document. Department of Social Development, Pretoria.

DSD (Department of Social Development), 2013. Department of social development customer service charter. Department of Social Development, Pretoria.

DSD (Department of Social Development), SASSA (South African Social Security Agency) \& UNICEF (United Nations Children's Fund), 2011. Child support grant evaluation 2010: Qualitative research report. UNICEF South Africa, Pretoria. http://www.unicef.org/ southafrica/resources_10734.html Accessed 4 August 2014.

DSD (Department of Social Development), SASSA (South African Social Security Agency) \& UNICEF (United Nations Children's Fund), 2012. The South African child support grant impact assessment: Evidence from a survey of children, adolescents and their households. UNICEF South Africa, Pretoria. http://www.unicef.org/southafrica/resources_10737.html Accessed 4 August 2014.

Du Toit, A \& Neves, D, 2009a. Informal social protection in post-apartheid migrant networks: Vulnerability, social networks and reciprocal exchange in the Eastern and Western Cape, South Africa. Brooks World Poverty Institute, University of Manchester. http://www.bwpi. manchester.ac.uk/medialibrary/publications/working_papers/bwpi-wp-7409.pdf Accessed 4 August 2014.

Du Toit, A \& Neves, D, 2009b. Trading on a grant: Integrating formal and informal social protection in post-apartheid migrant networks. Brooks World Poverty Institute, University of Manchester. http://www.bwpi.manchester.ac.uk/medialibrary/publications/working papers/bwpi-wp-7509.pdf Accessed 4 August 2014.

Esping-Andersen, G, 1989. The three political economies of the welfare state. The Canadian Review of Sociology and Anthropology/Revue canadienne de sociologie 26(1), 10-36.

Eyal, K \& Woolard, I, 2011. Female labour force participation and South Africa's child support grant. Paper presented at the Centre for the Study of African Economies 25th Anniversary Conference, 20-22 March, Oxford, UK.

Fultz, E \& Francis, J, 2013. Cash transfer programmes, poverty reduction and empowerment of women: A comparative analysis. Experiences from Brazil, Chile, India, Mexico and South Africa. International Labour Office, Geneva. http://www.ilo.org/wcmsp5/groups/public/dgreports/_gender/documents/publication/wcms_233599.pdf Accessed 4 August 2014.

Goldblatt, B, 2005. Gender and social assistance in the first decade of democracy: A case study of South Africa's child support grant. Politikon 32, 239-57.

Goldblatt, B, Rosa, S \& Hall, K, 2006. Implementation of the child support grant: A study of four provinces and recommendations for improved service delivery. Children's Institute, University of Cape Town. http://wiredspace.wits.ac.za/handle/10539/4683 Accessed 4 August 2014.

Haddock, J, 1996. Towards further clarification of the concept 'dignity'. Journal of Advanced Nursing 24, 924-31.

Hall, K \& Wright, G, 2010. A profile of children living in South Africa in 2008. Studies in Economics and Econometrics 34(3), 45-68.

Hickey, S, 2014. Relocating social protection within a radical project of social justice. European Journal of Development Research 26, 322-37.

Hochfeld, T \& Plagerson, S, 2011. Dignity and stigma among South African female cash transfer recipients. IDS Bulletin 42(6), 53-9. 
Khatib, R \& Armenian, H, 2010. Developing an instrument for measuring human dignity and its relationship to health in Palestinian refugees. World Medical and Health Policy 2(2), 33-47.

Liebenberg, S, 2005. The value of human dignity in interpreting socio-economic rights. South African Journal of Human Rights 1, 173-84.

Lund, F, 2008. Changing social policy: The child support grant in South Africa. HSRC Press, Pretoria.

Makiwane, M, Desmond, C, Richter, L \& Udjo, E, 2006. Is the child support grant associated with an increase in teenage fertility in South Africa? Evidence from national surveys and administrative data. Human Sciences Research Council, Pretoria. http://www.hsrc.ac.za/en/ research-data/view/3029 Accessed 4 August 2014.

Marshall, TH \& Bottomore, T (Eds.), 1992. Citizenship and social class. Pluto, London.

Martin, P, 2014. Children's rights to social assistance: A review of South Africa's child support grant. In Proudlock, P (Ed.), South Africa's progress in realising children's rights: A law review. Children's Institute, University of Cape Town and Save the Children South Africa, Cape Town, pp. 58-83.

Molyneux, M, 2007. Change and contiunity in social protection in Latin America: Mothers at the service of the state? United Nations Research Institute for Social Development, Geneva. http://www.unrisd.org/80256B3C005BCCF9/search/BF80E0A84BE41896 C12573240033C541?OpenDocument Accessed 4 August 2014.

Neves, D, Samson, M, Van Niekerk, I, Hlatshwayo, S \& Du Toit, A, 2009. The use and effectiveness of social grants in South Africa. FinMark Trust, Midrand. http://www. finmark.org.za/wp-content/uploads/r_socialgrants.pdf Accessed 4 August 2014.

Noble, M, Ntshongwana, P \& Surender, R, 2008. Attitudes to work and social security in South Africa. HSRC Press, Cape Town.

OECD (Organisation for Economic Cooperation and Development), 2011. Doing better for families. OECD Publishing, Paris.

Patel, L, Hochfeld, T, Moodley, J \& Mutwali, R, 2012. The gender dynamics and impact of the Child Support Grant in Doornkop, Soweto. Centre for Social Development in Africa, University of Johannesburg. http://ujdigispace.uj.ac.za/handle/10210/8268 Accessed 4 August 2014.

RSA (Republic of South Africa), 1996. The constitution of the republic of South Africa, section 1 of 1996. Government Printer, Pretoria.

RSA (Republic of South Africa), 1997. Batho Pele - 'People first': White paper on transforming service delivery. Government Gazette Vol.388, No.18340. Government Printer, Pretoria.

RSA (Republic of South Africa), 2004. Social assistance act no. 13 of 2004. Government Printer, Pretoria.

RSA (Republic of South Africa), 2009. Amendment to the social assistance act 2004, Government Gazette Vol.534, No.32853. Government Printer, Pretoria.

SADC (Southern African Development Community), 2003. Charter of fundamental social rights in SADC. Adopted by SADC Member States at Dar-es-Salaam, 26 August 2003.

SADC (Southern African Development Community), 2007. Code on social security in the SADC. http://www.sadc.int/files/2513/5843/3198/Code_on_Social_Security_in_SADC.pdf Accessed 4 August 2014.

SASSA (South African Social Security Agency), 2013a. You and your grants 2013/14, http://www. sassa.gov.za/Portals/1/Documents/05283ff8-ef75-4869-94b6-c026334269ef.pdf Accessed 4 August 2014.

SASSA (South African Social Security Agency) \& UNICEF (United Nations Children's Fund), 2013. Preventing exclusion from the child support grant: A study of exclusion errors in accessing CSG benefits. UNICEF South Africa, Pretoria.

Surender, R, Noble, M, Wright, G \& Ntshongwana, P, 2010. Social assistance and dependency in South Africa: An analysis of attitudes to paid work and social grants. Journal of Social Policy $39,203-21$.

UN (United Nations), 1948. The universal declaration of human rights. Adopted and proclaimed by General Assembly resolution 217 A (III) of 10 December 1948. http://www.un.org/en/ documents/udhr/ 
UN (United Nations), 1993. Vienna declaration and programme of action. Adopted by the World Conference on Human Rights in Vienna, 25 June 1993.

UNICEF, 2014. UNICEF South Africa annual report 2013. UNICEF South Africa, Pretoria.

Whitworth, A \& Noble, M, 2008. A safety net without holes: An argument for a comprehensive income security system for South Africa. Journal of Human Development 9(2), 247-63.

Williams, MJ, 2007. The social and economic impacts of South Africa's child support grant (Extended Version). EPRI Working paper 39. Economic Policy Research Institute, Cape Town.

Wright, G, Noble, M, Ntshongwana, P, Neves, D \& Barnes, H, 2014. The role of social security in respecting and protecting dignity of lone mothers in South Africa: Final report. Centre for the Analysis of South African Social Policy, University of Oxford.

Zembe, W, 2013. Good but not good enough: The limitations of a social assistance program for children in South Africa - The case of the Child Support Grant. DPhil thesis, University of Oxford. 